\title{
Tore Curstedt - The Basic Science Creator of Porcine Surfactant
}

\author{
Christian P. Speer ${ }^{\mathrm{a}}$ Henry L. Halliday ${ }^{\mathrm{b}}$

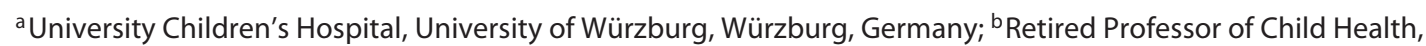 \\ Queen's University of Belfast, Belfast, UK
}

Tore Curstedt was born as an only child in 1946 in Piteå, a small town in the north of Sweden, about $800 \mathrm{~km}$ from Stockholm. He went to school in his hometown and in 1965 he moved to Stockholm for medical studies at the Karolinska Institutet. He started his research career in the Department of Medical and Physiological Chemistry at the Karolinska Institutet where, in 1974, he defended his doctoral thesis on Biosynthesis of Molecular Species of Phosphatidyl Cholines during Metabolism of $\left[1,1-^{2} H^{2}\right]$ Ethanol. His main project was to develop methods in order to follow the deuterium transfer from deuterated ethanol to acyl residues and to different positions of the glycerol moieties of individual molecular species of each phospholipid class [1-3]. New methods for the isolation and separation of phospholipids were developed, and the turnover of the individual molecular species of different phospholipid classes in tissues, bile and plasma was determined. In 1975, Tore became Associate Professor and Senior Lecturer in Medical Chemistry at the Karolinska Institutet. Five years later, he decided to become a laboratory doctor and moved to the Department of Clinical Chemistry at the Karolinska University Hospital but with his research group still belonging to the Karolinska Institutet. In 2004, Tore Curstedt was appointed Assistant Director with responsibility for the Karolinska University Laboratory, which is the largest clinical laboratory in northern Europe. He retired from that position last year but is still active in research.

\section{KARGER}

E-Mail karger@karger.com

www.karger.com/neo
Tore Curstedt

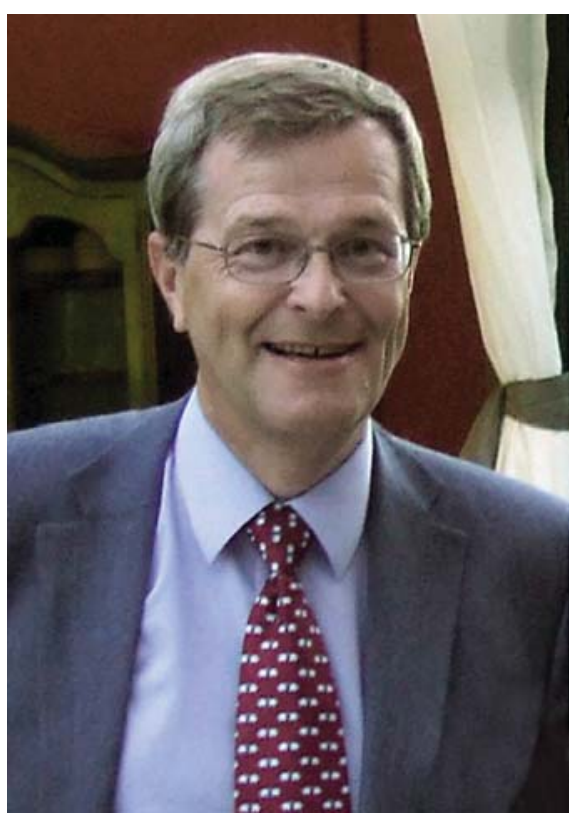

In 1980, two exceptional scientists met for the first time when they were both working at the Karolinska Institutet. Tore Curstedt and Bengt Robertson began their extraordinarily successful and long-lasting collaboration to develop a high-quality surfactant preparation, which could be produced in a reproducible way in large quanti-

Prof. Christian P. Speer, MD, FRCPE

University Children's Hospital, University of Würzburg

Josef-Schneider-Strasse 2

DE-97080 Würzburg (Germany)

E-Mail speer_c@ukw.de 
ties for the treatment of the neonatal respiratory distress syndrome [4]. Tore Curstedt's knowledge about the isolation, separation and identification of phospholipids and Bengt Robertson's knowledge about measuring surface activity in vitro using the pulsating bubble surfactometer and in vivo using immature newborn rabbits allowed the development of a surfactant preparation for the treatment of preterm babies. Their primary intention was to create a protein-free modified natural surfactant. A phospholipid fraction was isolated from minced porcine lungs and suspended in saline, but they soon realized that this preparation contained small amounts of hydrophobic proteins. The phospholipid fraction was successfully tested in vitro using the pulsating bubble surfactometer and in vivo on immature newborn rabbits [4, 5]. In 1983, the first preterm baby was successfully treated with surfactant in Stockholm on a humanitarian indication [6]. Since the surfactant had no name, Tore Curstedt and Bengt Robertson decided to call the surfactant Curosurf, a name coined from their surnames (Curstedt-Robertson-surfactant). Randomized European clinical trials were initiated in 1985 [7, 8], and during the 1980s more than two thousand treatment doses of Curosurf were prepared for the clinical trials in Tore Curstedt's department at the Karolinska University Laboratory. In the first randomized clinical trial, one group received the standard treatment at that time, and the surfactant-treated group had reduced mortality and pneumothorax [7]. In the 1980s and 1990s, many randomized clinical trials were performed, which established the effectiveness of Curosurf in the neonatal respiratory distress syndrome, the number of doses required, the benefits of prophylaxis for very preterm babies and the usefulness of Curosurf compared to other surfactant preparations. In December 1987, Tore Curstedt and Bengt Robertson started a collaboration with Chiesi Farmaceutici (Parma, Italy) for the largescale production of Curosurf ${ }^{\circledR}$ and development of a new generation of synthetic surfactant substitutes.

Tore Curstedt showed that the phospholipid fraction contained about $1-2 \%$ proteins which were not soluble in water but were so in organic solvents [5]. He succeeded in isolating the hydrophobic proteins from the phospholipids and in separating the proteins from each other [9]. These extremely hydrophobic peptides are now called SP-B and SP-C. He also identified one of the peptide fractions as containing palmitic acid molecules covalently linked to the cysteine residues in SP-C [10]. Together with Hans Jörnvall and Jan Johansson, he determined the primary and secondary structures of the two peptides SP-B and SP-C and they showed that SP-B was a homodi- mer with three intrachain disulfide bridges and one interchain disulfide bridge [10-14].

Tore Curstedt and Jan Johansson evaluated the possibility of developing a completely synthetic surfactant. They met several difficulties because pulmonary surfactant has a very complex composition with several species of phospholipids and with hydrophobic proteins which are responsible for adsorption and spreading the surfactant film at the air-liquid interface. These proteins have either too complex a structure to be synthesized or are structurally unstable in pure form [15]. These problems led to the development of synthetic surfactant preparations containing peptides, which may mimic the functions of the hydrophobic proteins SP-B and SP-C $[16,17]$. The peptides were combined with phospholipids and tested both in vitro and in vivo on immature newborn rabbits, and optimal activity could be obtained with an SP-B and SP-C analogue in a phospholipid mixture. These synthetic preparations were as effective as animalderived surfactant preparations in treating extremely immature newborn lambs with surfactant deficiency [18, 19]. A clinical trial with synthetic surfactant has started and the first treatment of preterm infants with respiratory distress syndrome shows promising results.

Tore Curstedt has published about 200 original articles, more than 30 review articles and some book chapters, and he continues to be active as the leader of his research group. He has been invited speaker or chairman at many international symposia and conferences all over the world on phospholipid metabolism, structure and function of hydrophobic surfactant proteins as well as natural and synthetic surfactants. He was awarded the Hilda and Alfred Eriksson's Prize by the Royal Swedish Academy of Sciences in 1998, the Lars Werkö Prize by the Swedish Heart Lung Foundation in 2004 (jointly with Bengt Robertson) and the Chiesi Price for Excellence in Neonatology in 2011.

Tore Curstedt, Bengt Robertson and others started the annual workshops on surfactant replacement in 1986, and in 2015 the ' 30 th International Workshop on Surfactant Replacement' will be at the Karolinska Institutet in Stockholm with Tore as president and with his very supportive wife Sol-Britt by his side. Tore Curstedt is one of very few basic scientists whose research, together with Bengt Robertson, has had such a major clinical impact on the morbidity and mortality of preterm infants. With his modest, open and friendly personality, Tore Curstedt fulfills an essential role in the ongoing success of basic and clinical surfactant research. 


\section{References}

1 Curstedt T: Biosynthesis of molecular species of phosphatidylcholines in bile, liver and plasma of rats given $\left[1,1-{ }^{2} \mathrm{H}_{2}\right]$ ethanol. Biochim Biophys Acta 1974;369:196-208.

-2 Curstedt T: Biosynthesis of acyl groups in molecular species of biliary phosphatidylcholines during metabolism of $\left[2,2,2-{ }^{2} \mathrm{H}_{3}\right]$ ethanol. Biochim Biophys Acta 1975;398:265-274.

-3 Curstedt T: Biosynthesis of molecular species of hepatic glycerophosphatides during metabolism of $\left[1,1-{ }^{2} \mathrm{H}_{2}\right]$ ethanol in rats. Biochim Biophys Acta 1982;713:589-601.

$>4$ Halliday HL, Speer CP: Bengt Robertson: a surfactant pioneer. Biol Neonate 2002;82: 272-273.

5 Robertson B, Curstedt T, Johansson J, Jörnvall $\mathrm{H}$, Kobayashi T: Structural and functional characterization of porcine natural surfactant isolated by liquid-gel chromatography. Prog Respir Res 1990;25:237-246.

-6 Noack G, Berggren P, Curstedt T, Grossmann G, Herin P, Mortensson W, Nilsson R, Robertson B: Severe neonatal respiratory distress syndrome treated with the isolated phospholipid fraction of natural surfactant. Acta Paediatr Scand 1987;76:697-705.

$>7$ Collaborative European Multicenter Study Group: Surfactant replacement therapy for severe neonatal respiratory distress syndrome: an international randomized clinical trial. Pediatrics1988;82:683-691.
$>8$ Speer CP, Robertson B, Curstedt T, Halliday HL, Compagnone D, Gefeller O, Harms K, Herting E, McClure G, Reid M, Tubman R, Herin P, Noack G, Kok J, Koppe J, van Sonderen L, Laufkötter E, Köhler W, Boenisch H, Albrecht K, Hanssler L, Haim M, Oetomo SB, Okken A, Altfeld PC, Groneck P, Kachel W, Relier JP, Walti H: Randomized European multicenter trial of surfactant replacement therapy for severe neonatal respiratory distress syndrome: single versus multiple doses of Curosurf. Pediatrics 1992;89:13-20.

-9 Curstedt T, Jörnvall H, Robertson B, Bergman T, Berggren P: Two hydrophobic lowmolecular-mass protein fractions of pulmonary surfactant. Characterization and biophysical activity. Eur J Biochem 1987;168: 255-262.

10 Curstedt T, Johansson J, Persson P, Eklund A, Robertson B, Löwenadler B, Jörnvall $\mathrm{H}$ : Hydrophobic surfactant-associated polypeptides: SP-C is a lipopeptide with two palmitoylated cysteine residues, whereas SP-B lacks covalently linked fatty acyl groups. Proc Natl Acad Sci USA 1990;87:2985-2989.

11 Johansson J, Jörnvall H, Eklund E, Christensen N, Robertson B, Curstedt T: Hydrophobic $3.7 \mathrm{kDa}$ surfactant polypeptide: structural characterization of the human and bovine forms. FEBS Lett 1988;232:61-64.

$>12$ Johansson J, Szyperski T, Curstedt T, Wüthrich $\mathrm{K}$ : The NMR structure of the pulmonary surfactant-associated polypeptide SP-C in an apolar solvent contains a valyl-rich $\alpha$-helix. Biochemistry 1994;33:6015-6023.

13 Curstedt T, Johansson J, Barros-Söderling J, Robertson B, Nilsson G, Westberg M, Jörnvall $\mathrm{H}$ : Low-molecular-mass surfactant protein type 1 . The primary structure of a hydrophobic 8 -kDa polypeptide with eight half-cystine residues. Eur J Biochem 1988;172:521-525.

14 Johansson J, Jörnvall H, Curstedt T: Human surfactant polypeptide SP-B. Disulfide bridges, C-terminal end, and peptide analysis of the airway form. FEBS Lett 1992;301:165-167.

15 Curstedt T, Calkovska A, Johansson J: New generation synthetic surfactants. Neonatology 2013;103:327-330.

16 Almlén A, Stichtenoth G, Linderholm B, Haegerstrand-Björkman M, Robertson B, Johansson J, Curstedt T: Surfactant proteins B and C are both necessary for alveolar stability at end expiration in premature rabbits with respiratory distress syndrome. J Appl Physiol 2008; 104:1101-1108.

17 Almlén A, Walther FJ, Waring AJ, Robertson B, Johansson J, Curstedt T: Synthetic surfactant based on analogues of SP-B and SP-C is superior to single-peptide surfactants in ventilated premature rabbits. Neonatology 2010; 98:91-99.

18 Sato A, Ikegami M: SP-B and SP-C containing new synthetic surfactant for treatment of extremely immature lamb lung. PLoS One 2012; 7:e39392.

19 Seehase M, Collins JJ, Kuypers E, Jellema RK, Ophelders DRMG, Ospina OL, Perez-Gil J, Bianco F, Garzia R, Razzetti R, Kramer BW: New surfactant with SP-B and C analogs gives survival benefit after inactivation in preterm lambs. PLoS One 2012;7:e47631. 